\title{
Fiber source and inclusion level affects characteristics of excreta from growing pigs
}

\author{
Conference Thando Mpendulo ${ }^{1}$, Michael Chimonyo ${ }^{1, *}$, Saymore Petros Ndou', and Archibold Garikayi Bakare ${ }^{1}$
}

* Corresponding Author: Michael Chimonyo Tel: +27-33-260-5477, Fax: +27-33-260-5067

E-mail: chimonyo@ukzn.ac.za

1 Animal and Poultry Science, School of Agricultural, Earth and Environmental Sciences, University of

KwaZulu-Natal, Scottsville 3209, South Africa

ORCID

Conference Thando Mpendulo

https://orcid.org/0000-0002-4375-1600

Michael Chimonyo

https://orcid.org/0000-0002-3244-0444

Submitted Aug 11, 2014; Revised Sept 19, 2014; Accepted Dec 22, 2014
Objective: The objective of the study was to determine the influence of varying fibrous diets on fecal characteristics of growing pigs.

Methods: A total of 104 pigs (initial weight $18 \pm 2.0 \mathrm{~kg}$ ) were used in the study. They were housed in individual pens and fed on diets containing maize cob, grass hay, lucerne hay, maize stover, and sunflower husk. These fibers were included at 0, 80, 160, 240, 320 and $400 \mathrm{~g} / \mathrm{kg}$. Fecal and urine samples were collected.

Results: Fecal output was largest amongst pigs fed on diets containing grass hay and maize stover $(\mathrm{p}<0.05)$. Nitrogen content was highest in feces from pigs fed on sunflower husk ( $\mathrm{p}<$ 0.05). Pigs fed on diets containing maize stover and maize cobs produced the largest concentrations of short chain fatty acids. Acetate concentration was high in feces of pigs fed maize stover than those fed grass hay and lucerne hay $(\mathrm{p}<0.05)$. As the level of fiber inclusion increased, fecal consistency and nitrogen content increased linearly $(p<0.05)$. Urea nitrogen decreased as the inclusion level increased across all the fibers $(p<0.05)$, with maize cobs containing the largest content of urea nitrogen. As dietary fiber content increased, fecal nitrogen content also increased $(\mathrm{p}<0.05)$.

Conclusion: It was concluded that different fiber sources influence fecal characteristics, thereby having different implications on pig waste management. It is vital to monitor fiber inclusion thresholds so as to easily manage environmental pollutants such as butyrate that contribute to odors.

Keywords: Dietary Fiber; Pig Excreta; Fecal Nitrogen

\section{INTRODUCTION}

Use of high quality feeds to maximize pig growth performance has also led to increased pollution levels from piggery units [1-3]. High quality feeds result to protein fermentation and increased intake of dietary nitrogen $[1,4]$. Inclusion of dietary fiber to pig diets increases fiber fermentation and the availability of desirable microbiota in the gut [2]. There is also evidence that inclusion of dietary fiber to pig diets results in dietary nitrogen shifting from the urea form in urine to bacterial form in feces, which is known to be less volatile $[1,2,4]$. Excreta cause unpleasant smell to residents near commercial piggeries [5]. One way to reduce pollution emanating from waste material from piggery units is the use of fibers [6-7]. In addition, fiber inclusion to pig diets reduces pollutants which contribute to global warming [7]. Different fiber sources have different physicochemical properties and are likely to influence characteristics of excreta of pigs. Decisions on choice and appropriate inclusion levels of dietary fiber should consider growth performance, availability of fiber, and its influence on environmental pollution.

Inclusion of dietary fiber at optimum levels to pig diets has been reported not to negatively impact pig performance [8-10]. In addition, effects of physicochemical properties of 
common fiber sources (maize cob [MC], grass hay [GH], lucerne hay $[\mathrm{LH}]$, maize stover [MS], and sunflower husk $[\mathrm{SH}]$ ) on voluntary feed intake have been examined [11]. These authors reported that feed intake decreased uniformly across fiber sources tested up to $160 \mathrm{~g} / \mathrm{kg}$ inclusion level. Increases in voluntary feed intake were observed when inclusion levels were increased to as high as $400 \mathrm{~g} / \mathrm{kg}$. At high fiber inclusion levels, pigs are expected to consume more feed to compensate for the reduction in nutrient density and for them to meet nutrient satiety. The gut capacity of the pigs, however, prevents them from continuing to increase voluntary feed intake. Consequently, growth performance starts to drop. The roles of such common fiber sources on excreta characteristics, however, still remain unclear. Dietary fiber sources differ in composition due to varying botanical origins and processing [9]. Such differences may alter the characteristics of the excreta, particularly feces and urine from growing pigs, but the extent with which these fibers influence excreta characteristics needs to be quantified. Understanding excreta characteristics is a first step in the management of effluents from piggery units. Knowledge of excreta characteristics empower pig producers to select feed ingredients that not only reduce feed costs, but also reduce the negative impacts of environmental pollution from pig units. The objective of the current study was to determine responses in characteristics of excreta, feces and urine from growing pigs fed on different fiber sources and fiber inclusion levels. It was hypothesized that varying fiber sources and inclusion levels of dietary fiber offered to growing pigs would alter the characteristics of feces, thereby reducing pollutants.

\section{MATERIALS AND METHODS}

\section{Study site and ethical aspects of the study}

The experiment was conducted at Ukulinga Research farm in Pietermaritzburg, South Africa. The farm lies $29^{\circ} 40^{\prime} \mathrm{S}, 30^{\circ} 24^{\prime} \mathrm{E}$ with an elevation of about $775 \mathrm{~m}$ above sea level. Daily temperatures average $29^{\circ} \mathrm{C}$, with variation ranging from $28.2^{\circ} \mathrm{C}$ to $43^{\circ} \mathrm{C}$. Mean annual rainfall is $735 \mathrm{~mm}$, falling mostly in summer with light to moderate frost occurring occasionally in winter [12]. The study was in compliance with the standards required by the Animal Ethics Committee of the University of KwaZulu-Natal (Reference no. 096/11/Animal).

\section{Pigs and housing}

Fifty two male F1 hybrid pigs (Large WhitexLandrace, PIC Group) weighing between $18 \pm 2.0 \mathrm{~kg}$ were used in the trial for each of the two runs. Pigs were confined in pens measuring $1.5 \times 1.0 \mathrm{~m}$ over 4 weeks. Each pen was fitted with a plastic tube feeder (Big Dutchman Lean Machine, Vechta, Lower Saxony, Germany) and a low-pressure nipple drinker providing water ad libitum. Feed was offered ad libitum as well. Pens were designed in such a way that feces and urine were collected separately. Temperature of the pig house was maintained at $23^{\circ} \mathrm{C}$ using an automated heating and ventilation system.

\section{Diets and experimental design}

Maize cobs, GH, LH, MS, and SH were fiber sources used in the experiment. Fibers were ground to pass through a $2 \mathrm{~mm}$ screen and diluted with a basal diet at $0,80,160,240,320$, and $400 \mathrm{~g} / \mathrm{kg}$ inclusion levels. The inclusions of the five fibers used in the current study were included in such a way that the contents of the basal diet were not compromised. The fibers were included to dilute the basal diet. The basal diet (Express Weaner) was purchased from a local feed manufacturing company (Meadow Feeds Limited) with a low level of dietary fiber of $50 \mathrm{~g} / \mathrm{kg}$ dry matter (DM) of total dietary fiber. Ingredients used in the formulation of basal diet were; yellow maize $(426 \mathrm{~g} / \mathrm{kg})$, soya bean $(176 \mathrm{~g} / \mathrm{kg})$, soybean oil cake $(83$ $\mathrm{g} / \mathrm{kg})$, wheat bran $(100 \mathrm{~g} / \mathrm{kg})$, whole wheat $(100 \mathrm{~g} / \mathrm{kg})$, sunflower oil cake $(75 \mathrm{~g} / \mathrm{kg})$, cape fish $(20 \mathrm{~g} / \mathrm{kg})$, and additives $(20 \mathrm{~g} / \mathrm{kg})$. There were a total of 26 complete diets offered to the pigs. The diets were composed of five varying fiber sources (MC, GH, LH, MS, and SH), included at five different inclusion levels of each fiber source (80, 160, 240, 320, and $400 \mathrm{~g} / \mathrm{kg}$ ), including the control diet. There were 26 treatments, with two pigs receiving the same treatment. The proximate composition of the 26 diets is given in Table 1. The experiment was repeated using the same design to ensure that each treatment combination had four pigs.

\section{Collection and storage of feces and urine}

Feces and urine were collected from each pig during the last three days of the experiment [13], when the experiment had run for a period of four weeks excluding adaptation period. Sacks were suspended underneath the pens, covering the whole surface area to ensure a total recovery of feces [14]. A total of $250 \mathrm{~g}$ of feces and $250 \mathrm{~mL}$ of urine were collected from each pig within an hour of excretion. Feces was collected in plastic bags and stored at temperatures of $-20^{\circ} \mathrm{C}$, pending analyses. Feces were collected in such a way that they did not mix with urine. Urine was only collected from pigs receiving 0,80 , and $160 \mathrm{~g} / \mathrm{kg}$ (MC, GH, LH, MS, and SH). Ndou et al [11] found inclusion threshold for the same fibers tested in the current study to have no impact on pig performance, such that the collection of urine beyond $160 \mathrm{~g} / \mathrm{kg}$ was largely unnecessary since growth performance was compromised at higher inclusion levels. Urine was collected in a bucket via a funnel below the pen. Meshed gauze was placed over the urine bucket to trap particulate. To prevent volatilization of ammonia, $2 \mathrm{~mL}$ of $25 \%$ sulphuric acid was added to each tray within 5 minutes of collection, and stored at $-20^{\circ} \mathrm{C}$ prior analysis of nitrogen. 
Table 1. Chemical composition of experimental diets, on as fed basis

\begin{tabular}{|c|c|c|c|c|c|c|c|c|c|}
\hline Fiber source & $\begin{array}{c}\text { Inclusion level } \\
(\mathrm{g} / \mathrm{kg})\end{array}$ & $\begin{array}{c}\text { Dry matter } \\
(\mathrm{g} / \mathrm{kg})\end{array}$ & $\begin{array}{c}\text { Gross energy } \\
\text { (kJ) }\end{array}$ & $\begin{array}{c}\text { Crude } \\
\text { protein } \\
(\mathrm{g} / \mathrm{kg})\end{array}$ & $\begin{array}{l}\text { Ether } \\
\text { extracts } \\
(\mathrm{g} / \mathrm{kg})\end{array}$ & $\begin{array}{l}\text { Ash } \\
(\mathrm{g} / \mathrm{kg})\end{array}$ & $\begin{array}{l}\text { Crude fiber } \\
(\mathrm{g} / \mathrm{kg})\end{array}$ & $\begin{array}{c}\text { Neutral } \\
\text { detergent } \\
\text { fiber }(\mathbf{g} / \mathbf{k g})\end{array}$ & $\begin{array}{c}\text { Acid } \\
\text { detergent } \\
\text { fiber }(\mathrm{g} / \mathrm{kg})\end{array}$ \\
\hline \multirow[t]{5}{*}{ Maize cob } & 80 & 989 & 18.0 & 181.7 & 51.2 & 59.0 & 36.4 & 210 & 101 \\
\hline & 160 & 990 & 17.9 & 168.1 & 45.9 & 54.9 & 47.9 & 234 & 127 \\
\hline & 240 & 990 & 17.9 & 152.8 & 45.2 & 53.2 & 59.3 & 355 & 181 \\
\hline & 320 & 990 & 17.9 & 139.4 & 41.3 & 52.1 & 70.8 & 401 & 218 \\
\hline & 400 & 991 & 17.8 & 116.4 & 39.9 & 46.7 & 82.2 & 457 & 250 \\
\hline \multirow[t]{5}{*}{ Grass hay } & 80 & 989 & 18.0 & 186.4 & 51.7 & 60.4 & 40.1 & 230 & 121 \\
\hline & 160 & 990 & 18.0 & 145.3 & 49.3 & 61.9 & 55.1 & 284 & 166 \\
\hline & 240 & 990 & 17.9 & 135.5 & 40.7 & 63.9 & 70.2 & 337 & 214 \\
\hline & 320 & 990 & 17.9 & 120.8 & 36.6 & 64.9 & 85.2 & 391 & 259 \\
\hline & 400 & 990 & 17.8 & 112.9 & 32.4 & 65.9 & 100.3 & 444 & 304 \\
\hline \multirow[t]{5}{*}{ Lucerne hay } & 80 & 989 & 18.1 & 192.6 & 49.2 & 63.1 & 46.0 & 228 & 101 \\
\hline & 160 & 990 & 18.0 & 187.0 & 45.2 & 65.1 & 67.0 & 261 & 126 \\
\hline & 240 & 990 & 18.0 & 174.0 & 41.5 & 67.2 & 87.9 & 301 & 150 \\
\hline & 320 & 989 & 17.9 & 168.5 & 39.2 & 69.2 & 108.9 & 343 & 175 \\
\hline & 400 & 989 & 17.9 & 165.9 & 33.3 & 71.3 & 129.9 & 385 & 200 \\
\hline \multirow[t]{5}{*}{ Maize stover } & 80 & 990 & 18.0 & 178.6 & 50.1 & 62.3 & 48.6 & 192 & 110 \\
\hline & 160 & 990 & 17.9 & 169.8 & 44.9 & 64.2 & 72.2 & 228 & 142 \\
\hline & 240 & 989 & 17.8 & 147.8 & 39.3 & 65.3 & 95.8 & 279 & 175 \\
\hline & 320 & 989 & 17.7 & 143.0 & 37.1 & 66.0 & 119.4 & 332 & 207 \\
\hline & 400 & 989 & 17.6 & 141.3 & 31.9 & 66.5 & 143.0 & 383 & 239 \\
\hline \multirow[t]{5}{*}{ Sunflower husk } & 80 & 989 & 18.2 & 184.9 & 54.1 & 56.6 & 55.6 & 243 & 94.5 \\
\hline & 160 & 989 & 18.3 & 166.7 & 55.4 & 53.8 & 86.3 & 269 & 110 \\
\hline & 240 & 989 & 18.5 & 134.6 & 55.7 & 51.6 & 116.9 & 316 & 126 \\
\hline & 320 & 989 & 18.7 & 132.1 & 56.6 & 48.5 & 147.6 & 363 & 142 \\
\hline & 400 & 989 & 19.0 & 123.5 & 57.3 & 44.9 & 178.2 & 409 & 157 \\
\hline Control diet & 0 & 989 & 18.1 & 195.7 & 52.9 & 61.1 & 26.1 & 192 & 88.4 \\
\hline
\end{tabular}

\section{Measurements}

Fecal consistency scoring was done during collection period on fresh feces using the hand-pressing method and visual appraisal devised by Strickling et al [15]. One person did the consistency scoring for all fecal samples. The descriptions of fecal consistency scores used are shown in Table 2. Dry matter, crude protein (CP), crude fat, crude fiber, nitrogen, and the ash content of feces were determined using procedures by the AOAC [16]. Neutral detergent fiber (NDF) and the acid detergent fiber $(\mathrm{ADF})$ were determined using a Fibertec extraction unit according to Van Soest et al [17]. Short chain fatty acid (SCFA) concentrations in feces, namely; acetate, propionate, isobutyrate, butyrate and valerate were determined according to Otto et al [4].

Table 2. Fecal consistency score used

\begin{tabular}{ll}
\hline Score & \multicolumn{1}{c}{ Description } \\
\hline 1 & Watery feces \\
2 & Smooth feces, with a fairly high moisture content \\
3 & Feces is a bit granular in texture, with a fair moisture content \\
4 & Firm feces with traces of fiber consumed \\
5 & Completely firm and coarse feces \\
\hline
\end{tabular}

\section{Statistical analyses}

Effects of dietary fiber source and inclusion level on fecal and urine output, fecal consistency, fecal and urine nitrogen and SCFA concentrations were analyzed using the general linear model procedure of SAS (SAS [18]). Pair-wise comparisons of means were performed using the PDIFF option. Data on fecal consistency were square-root transformed before analyses. The results were back-transformed when reporting. Regression analysis was used to compute the effect of fiber inclusion level on DM, fecal output, fecal consistency, fecal nitrogen, $\mathrm{CP}$, crude fat, $\mathrm{ADF}$, and NDF.

\section{RESULTS}

\section{Summary statistics and levels of significance}

The run had no effect on the parameters measured and was, therefore, ignored in the final statistical models used. Fiber source influenced DM, fecal output, fecal nitrogen, CP, NDF, $\mathrm{ADF}$, and isobutyrate $(\mathrm{g} / \mathrm{kg})(\mathrm{p}<0.01$; Table 3$)$, while total short chain fatty acid (TSCFA) concentrations and acetate were only influenced by fiber source $(\mathrm{p}<0.05$; Table 3$)$. Fiber inclusion level influenced DM, fecal output, fecal consistency, fecal nitrogen, $\mathrm{CP}, \mathrm{ADF}$, and NDF $(\mathrm{p}<0.01)$ crude fat levels in feces 
Table 3. Least square means ( \pm SEM) for the effect of fiber source on the composition of feces from growing pigs

\begin{tabular}{|c|c|c|c|c|c|c|}
\hline \multirow{2}{*}{ Parameter } & \multicolumn{5}{|c|}{ Fiber source } & \multirow{2}{*}{ SEM } \\
\hline & MC & GH & LH & MS & SH & \\
\hline DM (g/kg) & $196^{b}$ & $219^{b c}$ & $201^{b}$ & $163^{\mathrm{a}}$ & $234^{c}$ & 10.9 \\
\hline FO (g/kg DM/d) & $586^{\mathrm{a}}$ & $1,804^{c}$ & $790^{\mathrm{a}}$ & $1,335^{b}$ & $1,196^{b}$ & 125 \\
\hline FC (1 to 5 score) & $3.1^{\mathrm{a}}$ & $3.3^{\mathrm{ab}}$ & $2.8^{\mathrm{a}}$ & $3.1^{\mathrm{a}}$ & $3.6^{\mathrm{b}}$ & 0.22 \\
\hline Nitrogen (g/kg) & $2.2^{\mathrm{ab}}$ & $2.4^{b c}$ & $2.1^{\mathrm{a}}$ & $2.3^{\mathrm{ab}}$ & $2.6^{c}$ & 0.08 \\
\hline $\mathrm{CP}(\mathrm{g} / \mathrm{kg})$ & $13.8^{\mathrm{ab}}$ & $14.9^{\mathrm{bc}}$ & $13.2^{\mathrm{a}}$ & $14.7^{\mathrm{ab}}$ & $16.2^{c}$ & 0.51 \\
\hline Fat $(\mathrm{g} / \mathrm{kg})$ & $5.5^{\mathrm{a}}$ & $5.3^{\mathrm{a}}$ & $5.3^{\mathrm{a}}$ & $5.7^{\mathrm{a}}$ & $5.1^{\mathrm{a}}$ & 0.70 \\
\hline NDF $(\mathrm{g} / \mathrm{kg})$ & $816^{\mathrm{ab}}$ & $829^{a b}$ & $798^{\mathrm{a}}$ & $896^{b}$ & $752^{\mathrm{a}}$ & 30.3 \\
\hline ADF $(\mathrm{g} / \mathrm{kg})$ & $182^{\mathrm{a}}$ & $274^{\mathrm{bc}}$ & $239^{a b}$ & $290^{c}$ & $232^{\mathrm{ab}}$ & 19.8 \\
\hline TSCFA (g/kg DM) & $0.47^{\mathrm{a}}$ & $0.44^{\mathrm{a}}$ & $0.40^{a}$ & $0.44^{a}$ & $0.74^{b}$ & 0.055 \\
\hline Acetate (g/kg DM) & $0.21^{\mathrm{a}}$ & $0.19^{\mathrm{a}}$ & $0.17^{\mathrm{a}}$ & $0.26^{b}$ & $0.51^{b}$ & 0.052 \\
\hline Propionate (g/kg DM) & $0.09^{\mathrm{a}}$ & $0.11^{\mathrm{a}}$ & $0.08^{\mathrm{a}}$ & $0.08^{\mathrm{a}}$ & $0.11^{\mathrm{a}}$ & 0.012 \\
\hline Valerate (g/kg DM) & $0.02^{\mathrm{a}}$ & $0.03^{\mathrm{a}}$ & $0.03^{\mathrm{a}}$ & $0.02^{\mathrm{a}}$ & $0.03^{\mathrm{a}}$ & 0.007 \\
\hline
\end{tabular}

SEM, standard error of the mean; MC, maize cobs; GH, grass hay; LH, lucerne hay; MS, maize stover; SH, sunflower husk; DM, dry matter; FO, fecal output; FC, fecal consistency; CP, crude protein; Fat, crude fat; NDF, neutral detergent fiber; ADF, acid detergent fiber; TSCFA, total short chain fatty acids.

$a, b, c$ Within a row, values with the different superscripts differ $(p<0.05)$.

$(\mathrm{p}<0.05$; Figure 1). The interaction of fiber source $\times$ inclusion level for DM, fecal output, fecal consistency, fecal nitrogen, fecal protein, fecal fat, NDF, and ADF was not significantly different $(\mathrm{p}>0.05)$. There was, however a fiber sourcexinclusion level interaction influence on isobutyrate and butyrate concentrations ( $\mathrm{p}<0.01$; Table 4).
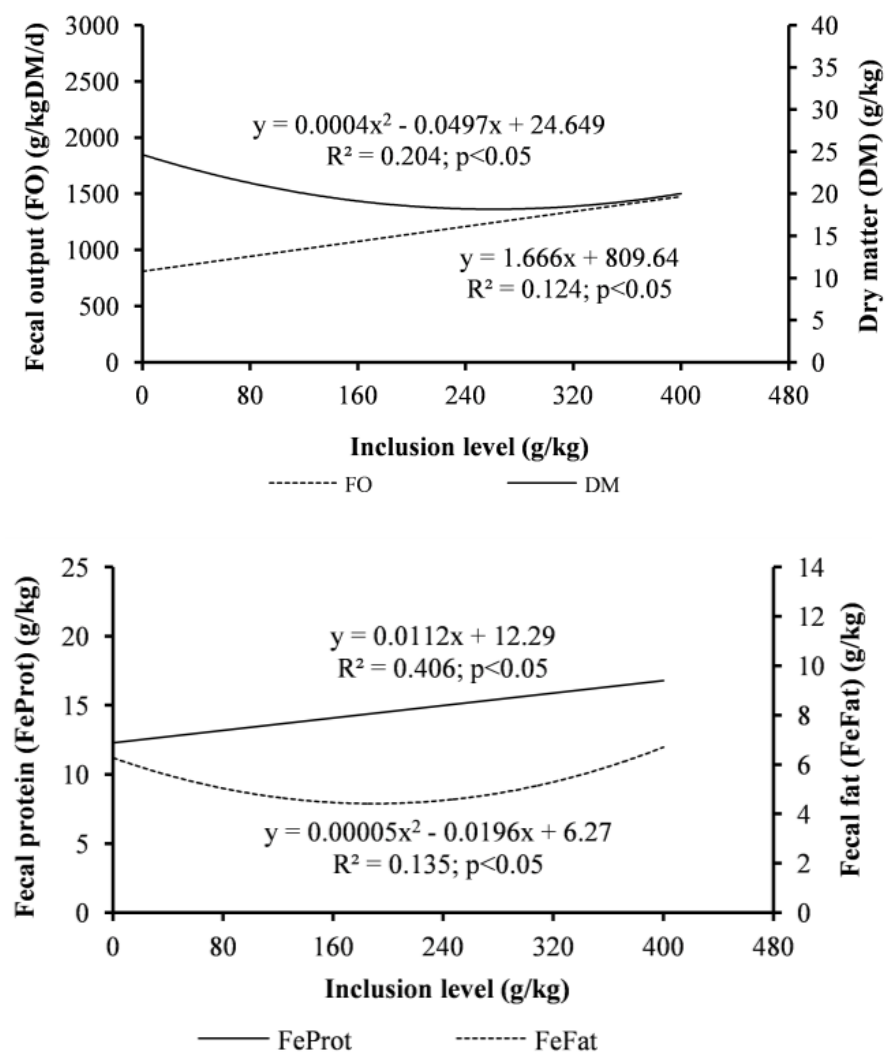

\section{Fecal composition}

Dry matter varied greatly with fiber source, with SH having the largest DM values compared to $\mathrm{MC}, \mathrm{GH}, \mathrm{LH}$, and MS $(\mathrm{p}<0.01$; Table 3). Pigs fed on diets containing GH, MS, and $\mathrm{SH}$ excreted more feces than pigs fed on either MC or LH containing diets $(\mathrm{p}<0.01$; Table 3$)$. Fecal consistency and nitrogen were similar across all fibers, except for pigs fed SH diets.
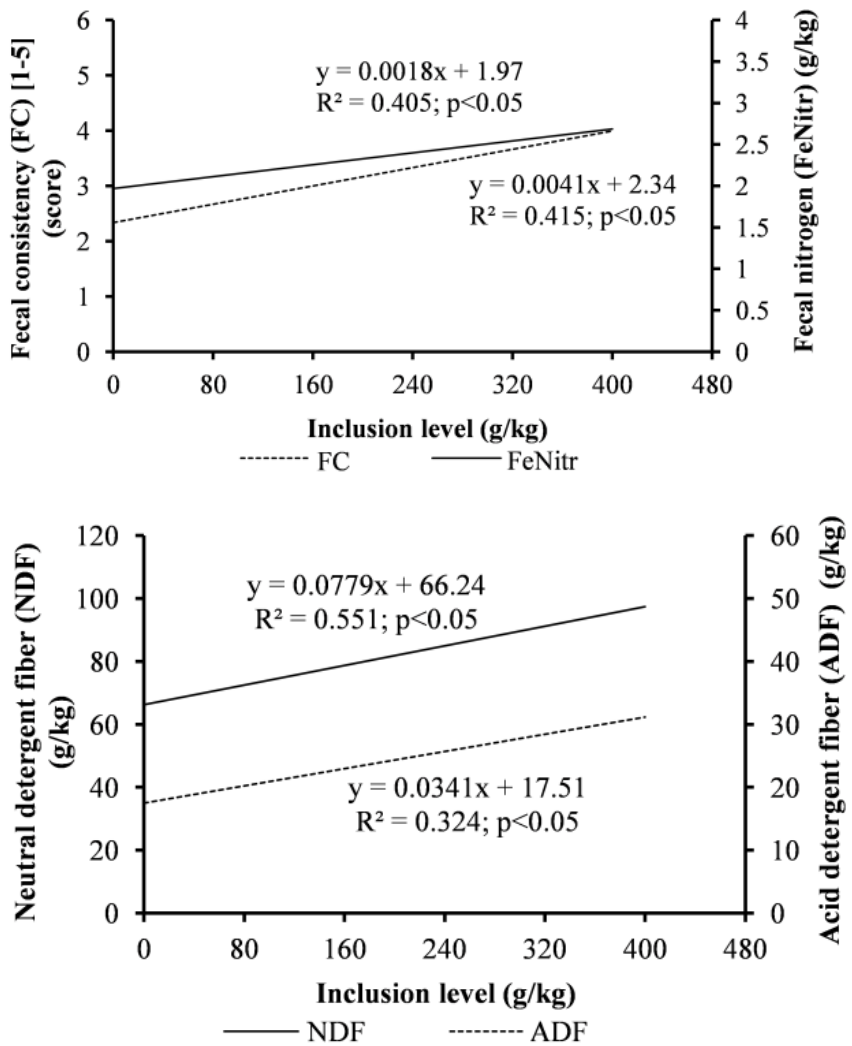

Figure 1. Effect of inclusion level of fiber on the physicochemical composition of feces from growing pigs. 
Table 4. Least square means ( \pm SEM) for the effect of fiber sourcexinclusion level of fiber source on isobutyrate and butyrate

\begin{tabular}{|c|c|c|c|c|c|c|c|c|}
\hline \multirow{2}{*}{ Parameter } & \multirow{2}{*}{ Fiber } & \multicolumn{6}{|c|}{ Inclusion level (g/kg) } & \multirow{2}{*}{ SEM } \\
\hline & & 0 & 80 & 160 & 240 & 320 & 400 & \\
\hline \multirow[t]{5}{*}{ I-but } & $\mathrm{MC}$ & $0.10^{\mathrm{a}}$ & $0.19^{\text {by }}$ & $0.27^{c y}$ & $0.37^{\mathrm{dz}}$ & $0.40^{\mathrm{dz}}$ & $0.39^{d y}$ & 0.025 \\
\hline & $\mathrm{GH}$ & $0.10^{\mathrm{a}}$ & $0.24^{c y}$ & $0.32^{d y}$ & $0.32^{c z}$ & $0.15^{\mathrm{abx}}$ & $0.18^{\text {by }}$ & 0.025 \\
\hline & $\mathrm{LH}$ & $0.10^{\mathrm{a}}$ & $0.15^{\mathrm{bx}}$ & $0.17^{b x}$ & $0.23^{\text {ay }}$ & $0.26^{\mathrm{cy}}$ & $0.31^{\mathrm{dz}}$ & 0.025 \\
\hline & MS & $0.10^{\mathrm{a}}$ & $0.13^{\mathrm{ax}}$ & $0.27^{\text {by }}$ & $0.13^{\mathrm{ax}}$ & $0.11^{\mathrm{ax}}$ & $0.10^{\mathrm{ax}}$ & 0.025 \\
\hline & $\mathrm{SH}$ & $0.10^{\mathrm{a}}$ & $0.12^{\mathrm{ax}}$ & $0.14^{\mathrm{ax}}$ & $0.14^{\mathrm{ax}}$ & $0.13^{\mathrm{ax}}$ & $0.11^{\text {ay }}$ & 0.025 \\
\hline \multirow[t]{5}{*}{ N-but } & MC & $0.24^{a}$ & $0.61^{\text {by }}$ & $0.63^{\text {by }}$ & $0.17^{\mathrm{ax}}$ & $0.83^{c y}$ & $0.56^{\text {by }}$ & 0.100 \\
\hline & $\mathrm{GH}$ & $0.24^{\mathrm{a}}$ & $0.37^{\text {aby }}$ & $0.27^{\mathrm{ax}}$ & $0.26^{\text {by }}$ & $0.25^{\mathrm{ax}}$ & $0.46^{\text {by }}$ & 0.100 \\
\hline & $\mathrm{LH}$ & $0.24^{\mathrm{a}}$ & $0.39^{\text {ay }}$ & $0.45^{\text {aby }}$ & $0.52^{\text {by }}$ & $0.39^{\mathrm{ax}}$ & $0.32^{\text {ay }}$ & 0.100 \\
\hline & MS & $0.24^{\mathrm{a}}$ & $0.17^{a x}$ & $0.20^{\mathrm{ax}}$ & $0.34^{\text {ay }}$ & $0.32^{\mathrm{ax}}$ & $0.33^{\text {ay }}$ & 0.100 \\
\hline & $\mathrm{SH}$ & $0.24^{\mathrm{a}}$ & $0.20^{\mathrm{ax}}$ & $0.27^{\mathrm{ax}}$ & $0.36^{\text {ay }}$ & $0.23^{\mathrm{ax}}$ & $0.20^{\mathrm{ax}}$ & 0.100 \\
\hline
\end{tabular}

SEM, standard error of mean; I-but, isobutyrate; MC, maize cob; GH, grass hay; LH, lucerne hay; MS, maize stover; SH, sunflower husk; N-but, butyrate.

$a, b, c, d$ Within a row, values with the different superscript letters differ $(p<0.05)$.

$x, y, z$ Within a column, values with the different superscript numerals are different $(p<0.05)$.

Nitrogen levels were largest in feces from pigs fed SH diets $(p<0.01)$. The NDF and ADF contents of the feces were largest from pigs fed on GH and MS compared to other fiber sources tested. Pigs fed on SH diets produced largest concentration of SCFA concentrations. Acetate concentration was largest from pigs fed $\mathrm{SH}$ diets $(\mathrm{p}<0.05$; Table 3$)$.

On the other hand, DM content of feces decreased as fiber inclusion level increased ( $p<0.05$; Figure 1). Fecal output, however, increased linearly as the level of fiber inclusion increased. As the level of fiber inclusion increased, both fecal consistency and nitrogen content increased ( $\mathrm{p}<0.05$; Figure 1), linearly. The CP content of feces increased linearly, whilst a curvilinear response was observed for fecal fat content with inclusion level of fiber. Both NDF and ADF increased linearly as the level of fiber inclusion increased.

Interaction of fiber source and inclusion level on short chain fatty acid concentration

Generally, isobutyrate concentration from pigs fed on MC and GH diets increased with fiber inclusion level and reached a peak at 240 and $320 \mathrm{~g} / \mathrm{kg}$ inclusion levels $(\mathrm{p}<0.05$; Table 4$)$. Isobutyrate for MS diets reached a maximum and peaked at $160 \mathrm{~g} / \mathrm{kg}$ inclusion level. For SH containing rations, isobutyrate was similar across all inclusion levels (Table 5). Butyrate concentrations for $\mathrm{LH}$ based diets increased with fiber inclusion levels ( $\mathrm{p}<0.05$; Table 4). For both MS and SH based diets, butyrate concentration was largest at $240 \mathrm{~g} / \mathrm{kg}$ inclusion level. Additionally, isobutyrate was smallest for MS and SH diets across all inclusion levels tested. Isobutyrate was largest for $\mathrm{GH}$ at 80 and $160 \mathrm{~g} / \mathrm{kg}$ fiber inclusion level, and tended to decline post $240 \mathrm{~g} / \mathrm{kg}$ fiber inclusion. At the same time, isobutyrate was largest for $\mathrm{MC}$ and $\mathrm{LH}$ at $240 \mathrm{~g} / \mathrm{kg}$ fiber inclusion levels and beyond. In general, butyrate was produced in largest concentrations from feces of pigs fed MC compared to those fed $\mathrm{SH}$ across fiber inclusion levels tested in the current study.
Effect of fiber source on urine nitrogen content, urine to nitrogen ratio and urine output

Table 5 shows urine nitrogen, fecal to urine nitrogen ratio and the amount of urine produced from pigs per day. Fiber source had no effect on urine nitrogen and output. As fiber levels increased, both urine nitrogen and output were reduced.

\section{DISCUSSION}

Plant species have different fibrous matrices and composition which determine the source of fiber and consequently their

Table 5. Least square means $( \pm S E M)$ for the effect of fiber sourcexinclusion level of fiber source on urine nitrogen content, urine to nitrogen ratio and urine output

\begin{tabular}{lcccc}
\hline \multirow{2}{*}{ Urinary patterns } & \multirow{2}{*}{ Fiber source } & \multicolumn{3}{c}{ Inclusion level $(\mathbf{g} / \mathbf{k g})$} \\
\cline { 3 - 5 } & & 0 & 80 & 160 \\
\hline Urine nitrogen $(\mathrm{g} / \mathrm{kg})$ & $\mathrm{OC}$ & $4.3^{\mathrm{a}}$ & $3.5^{\mathrm{ab}}$ & $3.0^{\mathrm{b}}$ \\
& $\mathrm{GH}$ & $4.3^{\mathrm{a}}$ & $0.8^{\mathrm{b}}$ & $0.8^{\mathrm{b}}$ \\
& $\mathrm{LH}$ & $4.3^{\mathrm{a}}$ & $2.6^{\mathrm{b}}$ & $1.0^{\mathrm{b}}$ \\
& $\mathrm{MS}$ & $4.3^{\mathrm{a}}$ & $1.8^{\mathrm{b}}$ & $1.6^{\mathrm{b}}$ \\
Fecal:urine nitrogen & $\mathrm{SH}$ & $4.3^{\mathrm{a}}$ & $1.1^{\mathrm{b}}$ & $1.4^{\mathrm{b}}$ \\
& $\mathrm{MC}$ & $0.5^{\mathrm{a}}$ & $0.6^{\mathrm{a}}$ & $0.8^{\mathrm{a}}$ \\
& $\mathrm{GH}$ & $0.5^{\mathrm{a}}$ & $2.9^{\mathrm{b}}$ & $2.9^{\mathrm{b}}$ \\
& $\mathrm{LH}$ & $0.5^{\mathrm{a}}$ & $0.7^{\mathrm{a}}$ & $2.0^{\mathrm{b}}$ \\
Urine output $(\mathrm{kg} / \mathrm{d})$ & $\mathrm{MS}$ & $0.5^{\mathrm{a}}$ & $1.3^{\mathrm{ab}}$ & $2.3^{\mathrm{b}}$ \\
& $\mathrm{SH}$ & $0.5^{\mathrm{a}}$ & $2.2^{\mathrm{b}}$ & $2.1^{\mathrm{b}}$ \\
& $\mathrm{MC}$ & $2.5^{\mathrm{a}}$ & $1.9^{\mathrm{a}}$ & $0.9^{\mathrm{a}}$ \\
& $\mathrm{GH}$ & $2.5^{\mathrm{a}}$ & $1.5^{\mathrm{a}}$ & $1.2^{\mathrm{a}}$ \\
& $\mathrm{LH}$ & $2.5^{\mathrm{a}}$ & $4.9^{\mathrm{b}}$ & $1.1^{\mathrm{a}}$ \\
& $\mathrm{MS}$ & $2.5^{\mathrm{a}}$ & $1.9^{\mathrm{a}}$ & $0.8^{\mathrm{a}}$ \\
& $\mathrm{SH}$ & $2.5^{\mathrm{a}}$ & $1.0^{\mathrm{ab}}$ & $0.7^{\mathrm{b}}$ \\
\hline
\end{tabular}

SEM, standard error of mean; MC, maize cob; GH, grass hay; LH, lucerne hay; MS, maize stover; $\mathrm{SH}$, sunflower husk.

$a, b$ Within a row, values with different superscripts in a row differ $(p<0.05)$.

SEM for urine nitrogen, fecal:urine nitrogen and urine output was $0.68,0.54$, and

0.87 , respectively. 
bulking capacities [11]. Such variation in composition of plant species might account for differences obtained for feces from diets with different fiber sources. Observation that fecal output was large from pigs fed fibrous diets was expected. High fecal output is attributed to indigestible fiber fraction in high fiber diets with GH, MS, and SH. Diets high in fiber have a greater portion of indigestible component which escapes fermentation in the gut compared to diets low in fiber $[19,20]$. Since pigs fed higher levels of increased fecal output, such can be attributed to increased indigestible components of the feed offered to pigs. This is because that, ADF and NDF are highly indigestible feed components, hence, they yielded larger fecal excretions from pigs fed increased fiber inclusion levels.

In the current study, feces from pigs fed higher fiber inclusion levels had higher fecal consistent scores than feces from pigs receiving diets with low inclusion levels of fiber. It is, therefore, important to confirm that one of the benefits of feeding fibrous diets in pigs is to reduce the occurrence of watery feces. The occurrence of watery feces in growing pigs is said to be a common experience for pigs post-weaning, caused by gastrointestinal upset due to various causes such as mal-fermentation of high protein diets [21], considering that growing pigs are fed high protein diets to ensure fast muscle development. In addition; diets with low fiber induce abnormal secretion of water and electrolytes in the colon [22], resulting in the formation of smeary feces. Therefore, high fecal consistency scores at higher fiber inclusion levels might have resulted from an increase in indigestible components of diets, ADF in particular as fiber levels were increased in pig diets $[19,3]$. On another note, Bindelle et al [23] reported an approximation of $22 \%$ of nitrogen to be bound to NDF in grasses. Schulze et al [24] reported only about $20 \%$ of the ingested NDF is digested by pigs, leaving a large proportion excreted with feces. Such outputs may vary with fiber source and the level of fiber inclusion of each fiber source because various fibers and levels have various compositions. Therefore, the ability of nitrogen to bind to the fiber varies with plant species, and impacts on the exposure of nitrogen for absorption by pigs. This accounts for variation in nitrogen and protein content in feces in diets with different fiber sources.

Kaun and Liong [25] observed fiber sources to have different soluble material. However, the secretion of water and electrolytes can be overturned by an infusion of SCFAs in the colon $[22,26]$. It is also vital to understand that, the production of SCFAs results from the deamination of undigested protein substrates (amino acids) and fermentation of soluble carbohydrates by anaerobic bacteria in the gastrointestinal tract and feces of pigs [4]. This could explain the largest production of acetate and SCFAs in general in the current study, considering that sunflower diets contained the largest protein content in the feces of pig. This is because that, diets with protein and carbohydrates that resist complete absorption before reaching the hindgut are likely to result to larger concentration of SCFAs in feces of pigs. At times, SCFAs are used as energy sources by pigs where nutrient availability to the pigs is limiting, which could have been the case for pigs fed on $\mathrm{GH}$ and MS. The SCFA concentrations in pigs fed on the highly indigestible GH and MS could have been used as energy sources. As observed in the current study, more SCFAs (butyrate) were produced from fermentation of high fibrous diets in the colon. This, thus, reduces secretion of water and electrolytes. The increase in the concentration of SCFA with increasing fiber content of pig diets depicts findings by Otto et al [4], who also found SCFAs to increase as the protein content of the pig diet was reduced. It is also important to consider that, the production of SCFAs is a result of anaerobic microbial fermentation of soluble carbohydrates in diets of pigs. Diets with high indigestible components of the diet (fiber) such as $\mathrm{SH}$ in the current study may have resulted to high usage of SCFAs as energy sources. This is because butyric acid is the main energy source for epithelial cells of the large intestines in growing pigs [27].

Observation that pigs fed fibrous diets yielded large fecal nitrogen, and that urinary nitrogen decreased simultaneously as fiber levels of pig diets increased, was expected. As much as the production of manure was increased in the current study as dietary fiber inclusion was increased, the repartitioning of nitrogen reduces nitrogen volatilization from pig units. High fecal nitrogen and low urinary nitrogen at high fiber levels explains the repartitioning of nitrogen, which results to more nitrogen being bonded with feces, rather than with urine [1-3]. Nitrogen bonded with feces is known to be of bacterial nature, and is known to be less volatile, as it is said to be bonded by the enzyme urease contained in feces $[1,5,20]$. This minimizes the loss of pollutants such as ammonia through volatilization [20].

\section{CONCLUSIONS}

Fiber inclusion in growing pig diets increases fecal output, SCFAs, and improves fecal consistency. Although manure production was increased, nitrogen content in urine was reduced resulting to more nitrogen bonded with feces, resulting to less volatilization of nitrogen. In addition, $\mathrm{MC}$ yielded much more isobutyrate and butyrate in the current study, which are known as malodor fermentation by-products. This means the inclusion of dietary fiber to pig diets alters the characteristics of growing pigs, thereby, reducing pollutants emitted from piggeries, thereby, not rejecting the hypothesis tested. The extent to which excreta characteristics are influenced depend on the properties of the fiber source used, and their selection should contribute towards the management of pollutants from piggeries. 


\section{CONFLICT OF INTEREST}

We certify that there is no conflict of interest with any financial organization regarding the material discussed in the manuscript.

\section{ACKNOWLEDGMENTS}

Authors would like to acknowledge financial support from the UKZN Competitive Research Grant, including the staff at the UKZN Ukulinga Research Farm and for their technical support. Additionally, financial support was also provided by the National Research Foundation of South Africa.

\section{REFERENCES}

1. Canh TT, Verstegen MWA, Aarnink AJA, Schram JW. Influence of dietary factors on nitrogen partitioning and composition of urine and feces of fattening pigs. J Anim Sci 1997; 75:700-6.

2. Nahm KH. Influences of fermentable carbohydrates on shifting nitrogen excretion and reducing ammonia emission of pigs. Crit Rev Environ Sci Technol 2003;33:165-86.

3. Jarret G, Cozannet P, Martinez J, Dourmad JY. Effect of different quality wheat dried distiller's grain solubles (DDGS) in pig diets on composition of excreta and methane production from faeces and slurry. Livest Sci 2011;140:275-82.

4. Otto ER, Yokoyama M, Hengemuehle S, et al. Ammonia, volatile fatty acids, phenolics, and odor offensiveness in manure from growing pigs fed diets reduced in protein concentration. J Anim Sci 2003;81:1754-63.

5. Aarnink AJA, Verstegen MWA. Nutrition, key factor to reduce environmental load from pig production. Livest Sci 2007;109: 194-203.

6. Mroz Z, Moeser AJ, Vreman K, et al. Effects of dietary carbohydrates and buffering capacity on nutrient digestibility and manure characteristics in finishing figs. J Anim Sci 2000;78: 3096-106.

7. Le PD, Aarnink AJA, Jongbloed AW. Odour and ammonia emission from pig manure as affected by dietary crude protein level. Livest Sci 2009;121:267-74.

8. Moore RJ, Kornegay ET, Grayson RL, Lindemann MD. Growth, nutrient utilization and intestinal morphology of pigs fed high-fiber diets. J Anim Sci 1988;66:1570-9.

9. Le Goff G, Noblet J, Cherbut C. Intrinsic ability of the faecal microbial flora to ferment dietary fibre at different growth stages of pigs. Livest Prod Sci 2003;81:75-87.

10. Cullen SP, Monahan FJ, Callan JJ, O'Doherty JV. The effect of dietary garlic and rosemary on grower-finisher pig performance and sensory characteristics of pork. Irish J Agric Food Res 2005;44:57-67.

11. Ndou SP, Gous RM, Chimonyo M. Prediction of scaled feed intake in weaner pigs using physico-chemical properties of fibrous feeds. Br J Nutr 2013;110:774-80.

12. Bengaly K, Mhlongo S, Nsahlai IV. The effect of wattle tannin on intake, digestibility, nitrogen retention and growth performance of goats in South Africa. Livest Res Rural Dev 2007;19: Article \#50.

13. Canh TT, Aarnink AJ, Verstegen MW, Schrama JW. Influence of dietary factors on the $\mathrm{pH}$ and ammonia emission of slurry from growing-finishing pigs. J Anim Sci 1998;76:1123-30.

14. Ouellet DR, Petit HV, Veira DM, Charmley E. Estimation of faecal output, digestibility, and intake using a controlled release capsule of alkanes in early and late lactation dairy cows fed two levels of concentrate. Can J Anim Sci 2004;84:277-89.

15. Strickling JA, Harmon DL, Dawson KA, Gross KL. Evaluation of oligosaccharide addition to dog diets: influences on nutrient digestion and microbial populations, Anim Feed Sci Technol 2000;85:205-19.

16. AOAC. Official methods of analysis, 18th ed. Association of Analytical Chemists. Washington, DC, USA: AOAC International; 2005.

17. Van Soest PJ, Robertson JB, Lewis BA. Carbohydrate methodology, metabolism, and nutritional implications in dairy cattle. J Dairy Sci 1991;74:3583-97.

18. SAS. SAS/STAT Software Release 9.2. Cary, NC, USA: SAS Institute Inc.; 2008.

19. Nagadi S, Herrero M, Jessop NS. The influence of diet of the donor animal on the initial bacterial concentration of ruminal fluid and in-vitro gas production degradability parameters. Anim Feed Sci Technol 2000;87:231-9.

20. Hansen MJ, Chwalibog A, Tauson AH. Influence of different fibre sources in diets for growing pigs on chemical composition of feces and slurry and ammonia emission from slurry. Anim Feed Sci Technol 2007;134:326-36.

21. Nijboer J, Clauss M, Everts H, Beynen AC. Effect of dietary fibre on the faeces score in colobine monkeys at Dutch Zoos. Zoo Anim Nutr 2006;3:145-55.

22. Ruppin H, Bar-Meir S, Soergel KH, Wood Jr. CM, Schmitt MG. Absorption of short-chain fatty acids by the colon. Gastroenterology 1980;78:1500-7.

23. Bindelle J, Sinnaeve G, Dardenne P, Leterme P, Buldgen A. A rapid estimation of nitrogen bound to neutral detergent fiber in forages by near infrared reflectance spectroscopy. In: Proceedings of the 10th International Grassland Congress. June 26th - July 1st, 2005. Dublin, Ireland: University College Dublin; 2005. $259 \mathrm{p}$.

24. Schulze H, van Leeuwen P, Verstegen MW, et al. Effect of level of dietary neutral detergent fiber on ileal apparent digestibility and ileal nitrogen losses in pigs. J Anim Sci 1994;72:2362-8.

25. Kuan YH, Liong MT. Chemical and physicochemical characterization of agro-waste fibrous materials and residues. J Agric Food Chem 2008;56:9252-7.

26. Mosenthin R, Hambrecht E, Sauer WC. Utilisation of different 
fibres in piglet feeds. In: Gransworthy PC, J Wiseman, editors. Recent developments in pig nutrition 3. Nottingham, UK: Nottingham University Press; 2001.
27. Biagi G, Piva A, Moschini M, Vezzali E, Roth FX. Performance, intestinal microflora, and wall morphology of weanling pigs fed sodium butyrate. J Anim Sci 2007;85:1184-1191. 